\author{
JUSTYNA STRYKOWSKA-NOWAKOWSKA \\ Uniwersytet im. Adama Mickiewicza \\ w Poznaniu
}

\title{
KOMPETENCJE KOMUNIKACYJNE NAUCZYCIELI
}

AвSTRACt. Strykowska Justyna, Kompetencje komunikacyjne nauczycieli [Teachers' Communicative Competences]. Studia Edukacyjne nr 45, 2017, Poznań 2017, pp. 311-328. Adam Mickiewicz University Press. ISSN 1233-6688. DOI: 10.14746/se.2017.45.21

The article discusses the problem of teachers' communicative competences and presents it from both the theoretical and empirical perspective. The first part of the article helps understand the communication process and defines teachers' communicative styles at school and barriers for pedagogical communication. The second part presents the results of diagnostic research on selected teachers' communicative competences. The research problems included: How do teachers understand the communication process at school, and what are the factors determining its level? What communicative styles do teachers use? What are the barriers in communication between teachers and students? The article concludes with remarks and postulates.

Key words: communicative competences, teachers, communication process, communicative styles and barriers

\section{Wstęp}

Rozważania teoretyczne i działania praktyczne związane z kompetencjami nauczycieli są obecne $\mathrm{w}$ dyskursie pedagogicznym już od dawna. Począwszy od starożytnych filozofów, humanistycznego renesansu i pozytywizmu, poprzez I połowę XX wieku (wyzwolony progresywizm), aż po dziś, naukowcy, praktycy i rodzice zastanawiają się, jaki jest i jaki powinien być nauczyciel - wychowawca.

Umiejętności komunikacji wychowawczej pedagogów trzeba traktować jako element składowy kompetencji wychowawczych nauczycieli. Nawiązując do takich autorów, jak: Maria Czerepaniak-Walczak ${ }^{1}$, Stanisław Dylak²,

${ }^{1}$ M. Czerepaniak-Walczak, Aspekty i źródła profesjonalnej refleksji nauczycieli, Torun 1997.

2 S. Dylak, Zawodowe kompetencje nauczyciela, [w:] Edukacja. Technologia kształcenia. Media, red. K. Denek, F. Januszkiewicz, W. Strykowski, Poznań 1993. 
Bogusława Gołębniak ${ }^{3}$, kompetencje wychowawcze będziemy rozumieć jako podmiotowe dyspozycje pedagogów, umożliwiające współuczestniczenie w procesie wychowania podopiecznych. Jest to całościowa struktura składająca się z określonej wiedzy, sposobu myślenia i rozumienia procesów, specyficznych umiejętności oraz stylów zachowania się nauczyciela.

Uruchamianie mechanizmów wychowawczych wymaga zaistnienia odpowiednich okoliczności. Podstawowy warunek stanowi nawiązanie podmiotowej relacji pomiędzy wychowawcą a wychowankiem, co jest możliwe tylko wówczas, kiedy nauczyciel potrafi prawidłowo komunikować się ze swoimi uczniami. Oznacza to posiadanie wiedzy z zakresu procesu komunikowania się i wynikających z niej konkretnych umiejętności słuchania, mówienia, a także wrażliwość na sygnały niewerbalne.

Proponowany artykuł przedstawia rozważania teoretyczne i wyniki badań empirycznych na temat komunikacji wychowawczej. Omówiono więc kolejno: rozumienie procesu komunikowania się, style komunikowania się w szkole oraz bariery w komunikowaniu wychowawczym. Drugą część artykułu stanowią wyniki badań diagnostycznych przeprowadzonych wśród czynnych nauczycieli.

\section{Rozumienie procesu komunikowania się}

Kluczem do tworzenia dobrej relacji pomiędzy wychowawcą a wychowankiem jest komunikacja wychowawcza. Terminem tym posługuje się Marek Dziewiecki, definiując komunikację wychowawczą jako podstawowe narzędzie formacji dzieci i młodzieży. Według niego, jest to rodzaj niezwykłego spotkania, dzięki któremu wychowanek ma szansę odkryć własną tajemnicę oraz dorastać do życia w prawdziwej miłości. Autor ten uważa, że istotą komunikacji wychowawczej jest zafascynowanie wychowanka dorastaniem do miłości i prawdy. Komunikacja wychowawcza wymaga całościowego i realistycznego rozumienia wychowanka, a także znajomości głównych celów i metod wychowania4.

Środkiem do osiągnięcia sukcesu są zdolności komunikacyjne. Według Zbigniewa Nęckiego ${ }^{5}$, jest to wiedza, jak i do kogo dotrzeć, jak budować relację i jak mówić, by słowa wspierały i rozwijały, a nie ograniczały i niszczyły słabszych. Innymi słowy - wiedza o komunikacji, umiejętność aktywnego słuchania, używania odpowiednich słów, a także wrażliwość na aspekty ko-

${ }^{3}$ B. Gołębniak, Nauczanie i uczenie się w klasie, [w:] Pedagogika. Podręcznik akademicki, t. 2, red. Z. Kwieciński, B. Śliwerski, Warszawa 2003.

${ }^{4}$ M. Dziewiecki, Komunikacja wychowawcza, Kraków 2004, s. 8-9.

${ }^{5}$ Z. Nęcki, Komunikacja międzyludzka, Kraków 1996. 
munikacji niewerbalnej powinny stanowić jednolitą, uwewnętrznioną całość. Nie wystarczy zatem przyswojenie danej wiedzy, ważna jest akceptacja i naturalne stosowanie jej w określonych sytuacjach.

Źródła pojęcia "komunikowanie” można szukać w języku łacińskim, gdzie communico, communicare oznacza uczynić wspólnym, połączyć, przekazać wiadomości, naradzać się. W komunikowaniu się duże znaczenie należy przykładać do przekazywania i łączenia. Ważne jest także wyróżnienie trzech podstawowych rodzajów komunikacji: intrapersonalnej, interpersonalnej i społecznej. Ta pierwsza to monolog wewnętrzny, kolejna zachodzi pomiędzy konkretnymi osobami, a ostatnia pomiędzy grupami ${ }^{6}$.

W opisywanym procesie komunikowania można wyszczególnić nadawcę i odbiorcę. Nadawca staje się odbiorcą, a odbiorca nadawcą po to, aby za chwilę role znów się odwróciły. Nauczyciel jest więc nadawcą i odbiorcą - powinien umieć funkcjonować w obu tych rolach. Zdarza się, że pedagodzy mają trudność z byciem dobrym odbiorcą uczniowskich komunikatów. Właściwe zrozumienie, a następnie praktyczna realizacja istoty komunikacji, to właśnie owa zależność i obopólne przenikanie się zachowań.

Nadawca ma określoną intencję, zamiar, myśl i uczucia, które koduje $\mathrm{w}$ postaci danej wiadomości, a następnie przekazuje ją do odbiorcy. Zadanie odbiorcy polega na właściwym odkodowaniu i interpretacji nadanego komunikatu. Styl komunikowania nauczyciela wpływa na reakcje ucznia. Odpowiednia wewnętrzna interpretacja tej reakcji determinuje kolejną wypowiedź nauczyciela. Przebieg tych pojedynczych sytuacji komunikowania się jest elementem wpływającym na całą relację pomiędzy wychowawcą a wychowankiem.

Proces komunikowania charakteryzuje się pewnymi cechami: jest złożony, społeczny i interakcyjny, dynamiczny, a także tworzy się w nim określona zależność. Społeczny element komunikacji pokazuje, że przebiega ona w jakimś kontekście i do jej realizacji potrzebne są co najmniej dwie osoby. Mówi się wówczas o komunikacji dotyczącej pojedynczego ucznia (komunikacja pomiędzy nauczycielem a uczniem). Oczywiście, istnieje także komunikacja grupowa. Istotne jest, w jaki sposób nauczyciel potrafi rozmawiać z każdym uczniem osobno i z całą klasą. Interakcyjność oznacza, że podczas komunikacji powinna zachodzić wzajemna wymiana. Najczęściej rozpoczyna się ona od spojrzeń, gestów, potem słów, informacji, później następuje wzrost zaufania. Dynamiczny charakter oznacza, że podczas jej przebiegu mają miejsce różne zjawiska psychiczne, takie jak: interpretowanie, rozumienie, akceptowanie lub odrzucanie słów bądź innych znaków.

${ }^{6}$ M. Mrozowski, Media masowe. Wtadza, rozrywka i biznes, Warszawa 2001, s. 29-30. 


\section{Style komunikowania się w szkole}

Nauczyciel bardzo często występuje w roli nadawcy komunikatów. Jest mówcą, gdy prowadzi lekcje, zajęcia wychowawcze z całą klasą, jest także nim podczas rozmowy z uczniem, rodzicem, z drugim nauczycielem, dyrektorem, czy też innym pracownikiem szkoły. W każdej z tych okoliczności w inny sposób się komunikuje. Umiejętność komunikacji polega na doborze odpowiednich słów w określonych sytuacjach. Nauczyciel podczas swojej pracy, w zależności od kontekstu sytuacji powinien używać różnych stylów komunikacji. Ich różne klasyfikacje można znaleźć w literaturze.

Często przytaczany i wykorzystywany jest podział na następujące style komunikowania się: agresywny, pasywny i asertywny ${ }^{7}$. Osoba o agresywnym stylu porozumiewania się potrafi z łatwością wyrazić swoje zdanie, myśli, chęci i zamiary. Czyni to jednak w sposób nieprzyjemny dla rozmówcy. Ma tendencję do obrażania go, poniżania, zdarza się, że nawet do wzbudzania w nim poczucia winy i niezadowolenia. Często przybiera styl atakowania rozmówcy, używając języka "ty”. Tak bowiem w psychoedukacji określa się mówienie nie o swoich potrzebach i intencjach, lecz o tym, co wydaje się komuś, że ma na myśli druga osoba i to, co komuś wydaje się, że o niej wie. Werbalnym przekaźnikiem jest stosowanie wulgaryzmów, epitetów lub słów oceniających z góry rozmówcę, ponadto uogólnień typu "zawsze", "nigdy" oraz wypowiedzi mocno sugerujących i ukazujących własną wyższość.

Styl pasywny jest typowy dla osób nieśmiałych, niepewnych samych siebie. Zdarza się, że mówią one cicho, jakby mówiły do siebie, używają słów pomniejszających znaczenie treści własnych wypowiedzi. Mają skłonność do podporządkowywania swoich poglądów, emocji i potrzeb poglądom innych osób. Osoby o stylu komunikowania się pasywnym, określanym także uległym, chciałyby, aby to rozmówcy domyślali się, co chcą powiedzieć, jakie są ich pragnienia. Trudno z nimi nawiązać kontakt wzrokowy, gdyż często patrzą w dół, ma się wrażenie, jakby uciekali wzrokiem.

Trzeci styl, najbardziej wskazany, to styl asertywny. Polega on na jasnym i stanowczym, a jednocześnie łagodnym sposobie wypowiadania się. Osoby takie potrafią wyrażać poglądy, myśli w taki sposób, aby nie ranić innych i okazywać im szacunek. Potrafią formułować prośby i jednocześnie są gotowe na przyjęcie odmowy oraz krytyki, charakteryzują się adekwatną samooceną, tak więc radzą sobie też z porównywaniem i oceną innych. Kontakt wzrokowy z takimi osobami jest łatwy i przyjemny. Wyprostowana postawa ciała wskazuje na emanujący od nich wigor.

\footnotetext{
${ }^{7}$ M. Król-Fijewska, Stanowczo, łagodnie, bez lęku, Warszawa 2012.
} 
Kolejny podział to styl autorytarny i współpracujący ${ }^{8}$. Pierwszy określany jest mianem stylu jednostronnego, co oznacza, że nauczyciel w procesie komunikacji odgrywa rolę dominującą, oczekuje od uczniów głównie słuchania i przyjmowania tego, co przekazuje. Nie ma tutaj miejsca na informacje zwrotne i pytania. Uczniowie nie mogą wyrażać swoich opinii i wpływać na otaczającą ich szkolną rzeczywistość. Najczęściej taki styl komunikowania się powoduje nieprzyjemny klimat emocjonalny w klasie. Wychowankowie nie chcą angażować się w zadania, za to czują przymus zewnętrzny i lęk przed nauczycielem. Nie przejawiają chęci identyfikowania się ze szkołą, którą najczęściej darzą nieprzyjemnym uczuciem. Styl współpracujący natomiast jest wzajemną wymianą wiadomości, poglądów i emocji. Występuje informacja zwrotna i zwrotne słuchanie się oraz dopełnianie. Uczniom daje to poczucie współtworzenia zadań, które wykonują, co zwiększa motywację i poczucie sensu z tego, co się robi.

Niezmiernie istotną umiejętnością, ważną dla nauczyciela, jest empatyczne rozumienie i empatyczne komunikowanie. W rozumieniu uczuć uczniów pomaga postawa empatii, czyli zdolność wejścia w świat dziecka. Empatia to zdolność dorosłego do pozytywnego zaangażowania emocjonalnego $\mathrm{w}$ relacjach z uczniem, tworzenia trafnych wyobrażeń na temat tego, co dzieje się w jego wewnętrznym świecie, umiejętność opisywania tych wyobrażeń, wrażliwość na jego reakcje, które mogą potwierdzić lub zanegować trafność tych wyobrażeń. Nauczyciel powinien zatem najpierw wniknąć w świat uczuć dziecka, rozpoznać, zrozumieć i nazwać jego emocje. Następnie tak poprowadzić rozmowę, aby uczeń sam dotarł do źródła swoich stanów wewnętrznych i w konsekwencji odnalazł rozwiązanie własnych trudności i problemów. Aby jednak do tego doszło, wychowawca powinien osiągnąć biegłość w konstruowaniu i zadawaniu pytań, gdyż ta umiejętność zachęca podopiecznego do samodzielnego myślenia, pozwala lepiej poznać siebie nawzajem, motywuje do działania. Ważne jest, aby mieć świadomość, jaki rodzaj pytania zastosować w określonej sytuacji.

Temu celowi służą pytania zamknięte i otwarte. Pierwsze rozpoczynają się najczęściej od słowa Czy i dają dwie możliwości odpowiedzi - tak i nie. Można je zatem stosować, gdy nauczyciel chce uzyskać konkretnie sprecyzowaną informację bądź usłyszeć określoną deklarację czy decyzję. Pytania zamknięte nie nadają się jednak do sytuacji, kiedy pragnie dowiedzieć się czegoś więcej o uczniu, gdy chce go poznać. Wtedy warto użyć pytań otwartych, zaczynających się od słów: Kto? Jaki? Co? Dlaczego? Gdzie? Kiedy? Dają one możliwość dłuższej wypowiedzi, podzielenie się doświadczeniami, opiniami, przeżyciami. Często aktywizują podopiecznych, motywują

\footnotetext{
${ }^{8}$ L. Grzesiuk, Style komunikacji interpersonalnej, Warszawa 1979.
} 
do działania, czy też pobudzają do dyskusji. Są także dobrym wstępem do definiowania, dookreślania zgłaszanych przez uczniów problemów, czy też do ich diagnozy.

\section{Bariery w komunikacji wychowawczej}

Proces komunikacji wychowawczej może być zakłócony, a nawet przerwany w wyniku błędów czy barier komunikacyjnych. Za dobrą komunikację odpowiedzialne są dwie rozmawiające ze sobą strony. Jednak w przypadku komunikacji wychowawczej, to po stronie dorosłego leży większy ciężar kreowania tej sytuacji. Dodatkowo, prowadzone rozmowy z uczniami jednocześnie stają się sytuacjami modelowania, co oznacza, że podczas ich trwania dziecko uczy się, jak rozmawiać z innymi ludźmi. Zatem, jeśli nauczyciel nie będzie potrafił komunikować się, to nie uda mu się porozumieć i jednocześnie będzie swój nieodpowiedni styl przekazywał dalej.

Istotne jest, aby unikać wypowiedzi, które mogą stanowić bariery i zakłócenia. Nauczyciel prowadząc rozmowę, powinien mieć na względzie to, w jaki sposób jego słowa wpływają na słuchającego go ucznia, jakie wewnętrzne reakcje powstają u rozmówcy, jakie myśli, jakie emocje i jakie zachowania są konsekwencją nauczycielskich komunikatów. Przyczyną niepowodzeń w komunikacji jest zbyt częste używanie słów mogących stanowić wyzwalanie trudnych emocji u słuchacza. Emocje te powodują, że uczeń traci motywację do komunikacji i ją przerywa.

W literaturze przedmiotu można odnaleźć wiele klasyfikacji błędów, barier, blokad, czy trudności w procesie komunikowania się. Thomas Gordon ${ }^{9}$ w swojej koncepcji wychowania bez porażek sporo miejsca poświęca blokadom komunikacji. Wyróżnia dwanaście typów blokad komunikacji interpersonalnej pomiędzy nauczycielem a uczniem. Tymi zagadnieniami zajmuje się także Beata Kozyra ${ }^{10}$, która w książce cały obszerny rozdział poświęca tego rodzaju barierom. Pisze ona o sześciu dużych grupach trudności, które następnie dzieli na konkretne rodzaje komunikatów. Zbigniew Nęcki we wspomnianej już książce Komunikacja międzyludzka wskazuje na osiem typów trudności w komunikacji.

Do barier w komunikacji należy grupa zwrotów, którą można nazwać wypowiedziami uwłaczającymi, poniżającymi. Są one wyrazem braku szacunku i akceptacji dla młodych rozmówców. Zalicza się do nich: obwinianie, oskarżanie, osądzanie, przezywanie, groźby i rozkazy. Tego typu wypowiedzi mogą stać się dla dziecka informacją, że jego osoba i jego potrzeby są dla

\footnotetext{
9 T. Gordon, Wychowanie bez porażek w szkole, Warszawa 2007.

${ }^{10}$ B. Kozyra, Komunikacja bez barier, Warszawa 2008.
} 
dorosłego nieważne. Nauczyciel oczekuje od wychowanka jedynie całkowitego podporządkowania przez wzbudzanie lęku. Uczeń może jednak odczuwać złość i wrogość, czemu będzie dawać wyraz swoim zachowaniem - oporem, nieposłuszeństwem i agresją.

Dorosłym czy wychowawcom zdarza się często, że ich rozmowy z dziećmi nasycone są sarkazmem bądź elementami dowcipkowania. Mogą one również stać się barierą w komunikacji. Informują one bowiem ucznia o tym, że nauczyciel nie interesuje się nim, nie szanuje jego uczuć, a nawet być może go nie akceptuje. Na takie komunikaty najczęściej pojawiają się reakcje typu: Jestem głupi, nic nie moge zapamiętać.

„Zakłócaczem" w komunikacji jest także nieumiejętne stosowanie ocen. Negatywna ocena charakteryzująca całą osobę może wyrządzić wiele szkód w kształtującej się osobowości. W szczególności narażona jest samoocena dziecka i budujący się wizerunek siebie, czyli sposób myślenia o sobie. Wskazana byłaby zdolność do empatii, czyli wnikliwego oraz wrażliwego zrozumienia przeżyć i odczuć ucznia ze strony nauczyciela.

Często zdarzającym się rodzajem komunikatu jest przyrównywanie danego dziecka do innego czy rodzeństwa lub do siebie samego. Nauczyciel porównując jednego ucznia, najczęściej słabszego w danej dziedzinie, z drugim lepszym ma nadzieję, że stanie się to motywacją i zachętą do większej pracy. Niestety, najczęściej jest inaczej. Uczeń mający być zmotywowany, czuje się upokorzony i zniechęcony, nie wierzy, że mógłby dorównać swojemu koledze lub bratu. Zagrożona jest więc relacja pomiędzy porównywanymi, może bowiem zrodzić się zazdrość i złość, czyli trudne emocje, z którymi młodzi ludzie nie zawsze potrafią sobie właściwie poradzić.

Zbyt szybka, odruchowa, wyrwana z szerszego kontekstu interpretacja bywa błędna i może być przyczyną zakłócenia w komunikacji. Ważne jest precyzyjne oddzielanie faktów, zdarzeń, konkretnych zachowań od ich analizy. Niewłaściwa interpretacja może wywołać w uczniach poczucie zdziwienia, zakłopotania, złości, czy też wstydu.

W komunikacji wychowawczej zdarzają się także wypowiedzi typu proroctwa. Nauczyciel prorokuje, na podstawie nieprawidłowego zachowania ucznia, że jego przyszłość będzie nieudana, np.: Ciagle kłamiesz, zobaczysz, już nikt nigdy tobie nie zaufa i już nigdy nie będziesz miat przyjaciót; nie uczysz się, zobaczysz, nie znajdziesz pracy $i$ do końca życia będziesz klepał biedę; jeśli dalej tak będziesz postępować, to na pewno skończysz w więzieniu. Tego typu wypowiedzi wzbudzają złość, lęk i odbierają siły do zmian swojego zachowania.

Trudnością w komunikacji pomiędzy nauczycielami a uczniami są uogólnienia i generalizowanie. Polegają one na konstruowaniu zbyt ogólnej oceny całej osobowości człowieka, czyli wyciąganiu negatywnego wniosku, dalece wykraczającego poza bieżącą sytuację. Nauczyciel formułuje ogólne zasady, 
zamiast mówić o konkretnych zachowaniach i własnych odczuciach. Używa takich słów, jak: zawsze, ciagle, już nigdy, do końca życia. Nadmierne uogólnienia odnoszą się także do samego siebie, np. Czułam się źle na zebraniu, więc nie nadaje się do bycia z ludźmi.

Zbyt częste stosowanie wykładów i moralizowania, czyli długich wypowiedzi nasyconych radami, rozciągniętym tłumaczeniem i negatywną oceną często stanowią początek zerwania komunikacji. Uczeń przy tego typu wypowiedziach nudzi się, nie jest w stanie zapamiętać wszystkiego i może doświadczać spadku samooceny.

Doradzanie, sugerowanie, proponowanie rozwiązań są takimi elementami komunikacji, które mogą być odbierane przez uczniów jako dowód, że nauczyciele nie wierzą $\mathrm{w}$ ich zdolności do samodzielnego rozwiązywania własnych problemów. Rada często jest odbierana jako komunikat: Wiem, co jest dla ciebie najlepsze, co może być irytujące dla młodych ludzi walczących o umocnienie swojej niezależności. Istotnym błędem nauczyciela jest niedowierzanie i zaprzeczanie wypowiedziom, a w szczególności emocjom wychowanków. Są to komunikaty typu: To niemożliwe, ty tego nie czujesz...; No co ty, przecież jest ciepło, nie może tobie być zimno. Takie komunikaty powodują, że dziecko zamyka się w sobie i w kolejnych sytuacjach może mieć trudności w podzieleniu się odczuciami. W komunikacji czasem zdarza się także wyolbrzymianie, czyli ukazanie czegoś w sposób przesadny. W tym wypadku podopieczny może poczuć się niesprawiedliwie oceniony, a nawet skrzywdzony. Efektem takich emocji jest strach, że jest aż tak źle.

Kolejną blokadą w komunikacji może być postawa męczennika. Częściej ten typ komunikacji zdarza się u rodziców, ale jest także możliwy u nauczycieli. Dorosły w swoich wypowiedziach przedstawia siebie jako osobę, która robi wszystko dla dziecka, a ono jest niewdzięczne i nie potrafi się odpowiednio zachowywać i docenić jego starań. Taka postawa wzbudza u młodego człowieka zbyt obciążające poczucie winy, które może stać się przyczyną licznych trudności.

\section{Badania kompetencji komunikacyjnych wśród nauczycieli}

W dalszej części artykułu zostaną zaprezentowane wyniki badań diagnostycznych, mających na celu rozpoznanie kompetencji komunikacyjnych wybranych nauczycieli. Byli to nauczyciele szkoły podstawowej i gimnazjum - słuchacze studiów podyplomowych dla nauczycieli o specjalności przyroda, historia i zarządzanie oświatą. Grupę badawczą stanowili więc czynni 
nauczyciele, uczący takich przedmiotów, jak: chemia, biologia, geografia, historia, religia, język angielski i niemiecki, sztuka, wychowanie fizyczne oraz nauczyciele wychowania przedszkolnego i wychowawcy świetlicy szkolnej. W rezultacie próbę badawczą (160 osób) w omawianych tu badaniach stanowiła grupa nauczycieli-wychowawców z całej Polski.

Badanie zostało przeprowadzone za pomocą rozbudowanego kwestionariusza ankiety. Diagnoza kompetencji komunikacyjnych powstała w wyniku samooceny, to znaczy nauczyciele sami określali występowanie oraz kształt i poziom konkretnego elementu kompetencji komunikacyjnych. Badanie diagnostyczne miało na celu uzyskanie odpowiedzi na następujące pytania ogólne:

- Jak nauczyciele rozumieja proces komunikowania się w szkole i jakie czynniki warunkuja jego poziom?

- Jakie style komunikowania się stosuja nauczyciele?

- Jakie bariery występuja w komunikacji pomiędzy nauczycielami a uczniami?

\section{Rozumienie przez nauczycieli procesu komunikowania się w szkole i czynniki warunkujące jego poziom}

Pierwszy obszar, jaki poddano badaniom w kwestii kompetencji komunikacyjnych nauczycieli, to rozumienie procesu komunikacji, jego uwarunkowań, oraz samoocena poziomu kompetencji komunikacyjnych.

W celu poznania, w jaki sposób nauczyciele definiują proces komunikowana, zostało im zadane pytanie otwarte: czym dla Pani/Pana jest proces komunikowania się w szkole? Najczęściej padały odpowiedzi, że proces komunikowania się $\mathrm{w}$ szkole zachodzi pomiędzy nauczycielem a uczniem, pomiędzy uczniem a nauczycielem, nauczycielem a nauczycielem, nauczycielem a rodzicami oraz nauczycielami a dyrekcją. Do opisu procesu komunikowania się używano określeń: dialog, dobre relacje, bardzo ważna umiejętność nauczycieli, sposób na wzajemne poznawanie się, zrozumienie oczekiwań i potrzeb uczniów. Zwracano także uwagę na to, że rozmowa to rozwiązywanie problemów i powinna przebiegać w sposób przyjazny. Ta grupa nauczycieli była najliczniejsza - liczyła 78 osób. Drugą grupę stanowili nauczyciele traktujący komunikację w szkole jako sposób na transmisję wiedzy, jako przepływ informacji. Istotna wtedy staje się efektywność komunikacji, rozumiana jako przekazanie określonej treści. Do tej grupy można zaliczyć 68 osób. Trzecią grupę tworzy tylko 14 osób, które zwróciły uwagę na odpowiedni dobór słów na ich piękno i adekwatność względem sytuacji komunikowania się. 
W procesie doskonalenia kompetencji wychowawczych, w zakresie komunikacji wychowawczej, istotne są przekonania odnośnie do ich uwarunkowań. Zasadniczą sprawą jest odpowiedź na pytanie: Czy podczas specjalistycznych zajęć typu warsztaty i treningi można doskonalić swoją komunikacje? W celu zbadania tego zagadnienia zadano nauczycielom dwa pytania - jedno o przekonania w stosunku do uwarunkowań tych umiejętności i drugie o uczestnictwo w kursach bezpośrednio związanych z komunikacją. W pytaniu o uwarunkowania respondenci mogli wybrać jedną odpowiedź z następujących propozycji: uczestnictwo w specjalistycznych kursach i szkoleniach $\mathrm{z}$ zakresu komunikowania się, zdobyte doświadczenia $\mathrm{w}$ relacji z uczniami, cechy osobowościowe (tab. 1).

Tabela 1

Czynniki warunkujące umiejętności komunikowania się

\begin{tabular}{|l|c|c|}
\hline \multicolumn{1}{|c|}{ Grupy uwarunkowań } & Liczba osób n = 160 & $\%$ \\
\hline $\begin{array}{l}\text { Uczestnictwo w specjalistycznych kursach } \\
\text { i szkoleniach z zakresu komunikowania się }\end{array}$ & 12 & 7,50 \\
\hline Zdobyte doświadczenia w relacji z uczniami & 98 & 61,25 \\
\hline Cechy osobowościowe & 50 & 31,25 \\
\hline
\end{tabular}

Źródło: badania własne.

Najwięcej osób, bo aż 98 (61,25\%) zadeklarowało, że swoją komunikację najbardziej doskonali w wyniku zdobytych doświadczeń w relacjach z uczniami. 50 osób (31,25\%) wskazało na cechy osobowościowe, 12 (7,50\%) - na uczestnictwo w kursach i szkoleniach.

Pytanie o formy doskonalenia było pytaniem otwartym. Prawie połowa osób nie odpowiedziała na nie, 12 nauczycieli udzieliło odpowiedzi, że nie uczestniczyło w tego typu szkoleniach, wśród pozostałych najczęściej pojawiały się odpowiedzi, że uczestniczyli w warsztatach, w których była także mowa o komunikacji. Pięć osób wymieniło konkretne kursy: komunikacja pomiędzy nauczycielem a uczniem, podstawy komunikacji interpersonalnej. Pojawiały się także informacje o uczestnictwie w konferencjach, podczas których była mowa o komunikacji.

W pytaniu o określenie poziomu swoich umiejętności nauczyciele mieli do dyspozycji trzy warianty: poziom wysoki, średni i niski. Najwięcej odpowiedzi można zakwalifikować do poziomu średniego 79 osób (49,37\%), ale równie dużo, gdyż 37 osób (23,12\%) określiło swój poziom jako wysoki, 17 osób nie udzieliło odpowiedzi, 27 zaznaczyło niski (tab. 2). 
Samoocena poziomu umiejętności komunikowania się

\begin{tabular}{|l|c|c|}
\hline \multicolumn{1}{|c|}{ Poziom } & Liczba osób $\mathrm{n}=160$ & $\%$ \\
\hline Wysoki & 37 & 23,12 \\
\hline Średni & 79 & 49,37 \\
\hline Niski & 27 & 16,87 \\
\hline Brak odpowiedzi & 17 & 10,62 \\
\hline
\end{tabular}

Źródło: badania własne.

\section{Style komunikowania się stosowane przez nauczycieli}

Kolejnym badanym obszarem kompetencji komunikacyjnych nauczycieli był styl komunikowania się w szkole. W części teoretycznej opisano kilka stylów komunikowania się, jak np.: agresywny, pasywny, asertywny oraz autorytarny i współpracujący. Elementem stylu komunikowania się jest też empatyczne rozumienie oraz potrzebna do tego umiejętność słuchania i zadawania pytań.

W celu zbadania, jak opisane i wymienione powyżej rodzaje stylów komunikowania się funkcjonują w praktyce szkolnej, postawiono badanym następujące zadania i pytania:

1) tabelka kwestionariuszowa, w której nauczyciele mieli wskazać, jak często używają określonych zachowań komunikacyjnych, umożliwiająca określenie miejsca nauczycielskiej komunikacji na skali - od komunikacji autorytarnej, poprzez mieszaną, aż do komunikacji współpracującej (tab. 3);

Tabelka kwestionariuszowa

Tabela 3

Jak często wobec uczniów zachowuje się Pan/Pani w opisany poniżej sposób?

\begin{tabular}{|c|l|l|l|l|l|}
\hline & & Zawsze & Często & $\begin{array}{c}\text { Trudno } \\
\text { określić }\end{array}$ & Nigdy \\
\hline 1 & $\begin{array}{l}\text { Toleruję odmienność poglądów } \\
\text { i przekonań uczniów }\end{array}$ & & & & \\
\hline 2 & $\begin{array}{l}\text { Od uczniów oczekuję głównie tego, } \\
\text { aby mnie słuchali }\end{array}$ & & & & \\
\hline 3 & $\begin{array}{l}\text { Zdarza mi się obwiniać rozmówcę } \\
- \text { ucznia }\end{array}$ & & & & \\
\hline 4 & $\begin{array}{l}\text { Mam skłonność do zbyt długich } \\
\text { kazań }\end{array}$ & & & & \\
\hline 5 & $\begin{array}{l}\text { Staram się uzgadniać z uczniami } \\
\text { ważne dla nich kwestie }\end{array}$ & & & & \\
\hline
\end{tabular}




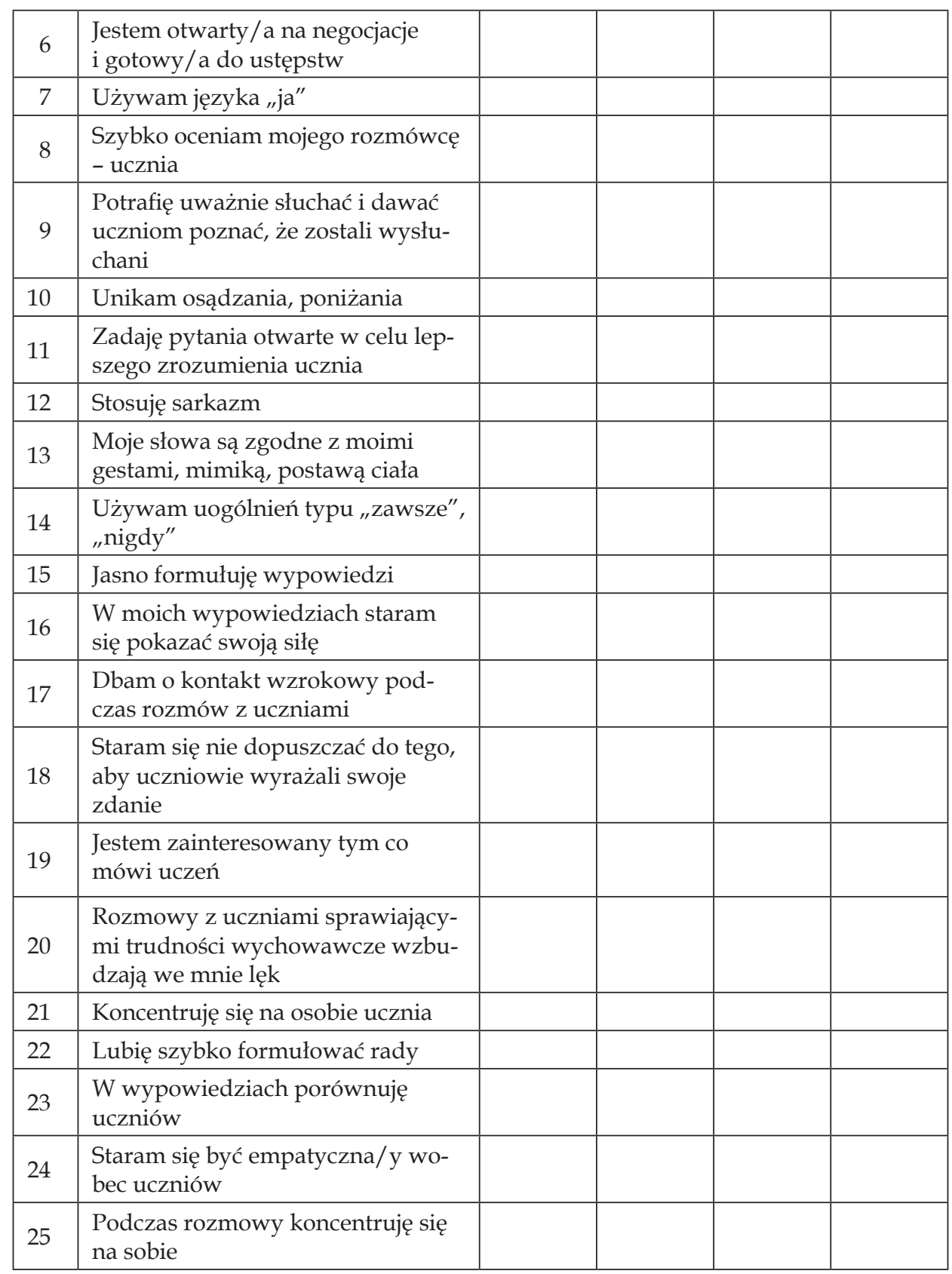

2) seria pytań: w pierwszym respondenci sami mieli opisać swój styl komunikowania się, w kolejnym zaznaczali, jaki rodzaj pytań najczęściej wykorzystują, pojawiło się także pytanie o odzwierciedlanie uczuć i empatię. 
Pytanie, w którym badani mieli zaznaczyć częstość ich określonych zachowań komunikacyjnych było tabelką kwestionariuszową, umożliwiającą usytuowanie stylu komunikowania się na skali - styl autorytarny versus styl współpracujący. Miejsce na niej zależy od liczby uzyskanych punktów. Wyniki zaprezentowano $\mathrm{w}$ tabeli 4 .

Tabela 4

Styl komunikowania się charakterystyczny dla nauczycieli

\begin{tabular}{|l|c|c|}
\hline \multicolumn{1}{|c|}{ Nazwa stylu i liczba punktów } & $\begin{array}{c}\text { Liczba osób } \\
\mathrm{n}=160\end{array}$ & $\%$ \\
\hline Autorytarny 0 - 25 & 15 & 9,40 \\
\hline Pośredni/mieszany 26 - 50 & 69 & 43,10 \\
\hline Współpracujący 51 - 75 & 76 & 47,50 \\
\hline
\end{tabular}

Źródło: badania własne.

W nawiązaniu do pytania o styl komunikowania respondenci używali następujących słów i wyrażeń: prosty, zwięzły, bez oceniania, empatyczny, otwarty, chętnie słucham, pozwalam się uczniom wypowiadać, zrozumiały, przyjazny, spokojny, z poczuciem humoru, toleruję odmienność, negocjuję, unikam osądzania, poświęcam czas, spokojny, szczery, interaktywny, podmiotowy, empatyczny, wspierający, konkretny, łagodny, nie stosuję krytyki, unikam tonu rozkazującego, skoncentrowany na potrzebach ucznia. Jedna osoba napisała, że używa komunikatów typu „ja”, a inna, że jest stanowcza. Taki sposób opisywania swojego stylu wskazuje na humanistyczne podejście do komunikowania się.

W odpowiedzi na pytanie: Na czym polega odzwierciedlanie uczuć? padały określenia, że jest to ujawnianie uczuć, nazywanie ich, bycie empatycznym. Wszyscy badani wskazali, że empatia rozumiana jako wczuwanie się w stan emocjonalny drugiej osoby jest ważna w komunikacji wychowawczej.

W celu zbadania rodzaju najczęściej zadawanych pytań nauczyciele mieli do wyboru cztery opcje: pytania otwarte, zamknięte, naprowadzające, zaczynające się od słowa "dlaczego?". Wyniki zostały przedstawione w tabeli 5.

Tabela 5

Element składowy stylu komunikowania się: rodzaj stosowanych pytań

\begin{tabular}{|l|c|c|}
\hline \multicolumn{1}{|c|}{ Rodzaj stosowanych pytań } & Liczba osób $\mathrm{n}=160$ & $\%$ \\
\hline Otwarte & 75 & 46,90 \\
\hline Zamknięte & 28 & 17,50 \\
\hline Naprowadzające & 33 & 20,60 \\
\hline Zaczynające się od słowa "dlaczego" & 24 & 15,00 \\
\hline
\end{tabular}

Źródło: badania własne. 


\section{Bariery w komunikacji pomiędzy nauczycielami a uczniami}

Umiejętność rozpoznawania barier w swoim stylu komunikowania stanowi ważny element badanych kompetencji. Wymaga to znajomości, przedstawionej w części teoretycznej artykułu, klasyfikacji błędów oraz autorefleksji nad własną komunikacją. $\mathrm{W}$ badaniach zostało zatem postawione pytanie: Jakie bariery występuja w komunikacji pomiędzy nauczycielami a uczniami? W celu uzyskania odpowiedzi na tak postawiony problem skonstruowano zadanie dla respondentów, zawierające 14 wypowiedzi, z czego dziewięć stanowiło bariery. Należało zaznaczyć komunikaty - bariery i wskazać, gdzie jest błąd. Rozpoznawanie nieprawidłowości w komunikatach prezentuje tabela 6.

Rozpoznawanie błędów w komunikacji

Tabela 6

\begin{tabular}{|c|c|c|c|}
\hline Komunikat & Treść komunikatu & $\begin{array}{l}\text { Liczba osób, } \\
\text { które wskazały, } \\
\text { że dany komuni- } \\
\text { kat jest błędem }\end{array}$ & $\%$ \\
\hline $\begin{array}{l}\text { Stosowanie } \\
\text { ocen, wyol- } \\
\text { brzymianie }\end{array}$ & Masz kiepskie oceny, bo jesteś leniwy. & 50 & 31,25 \\
\hline $\begin{array}{l}\text { Porównywa- } \\
\text { nie }\end{array}$ & $\begin{array}{l}\text { Dlaczego nie jesteś bardziej podobny do swo- } \\
\text { jego brata? On, w przeciwieństwie do ciebie, } \\
\text { jest pilny i odpowiedzialny. }\end{array}$ & 99 & 61,87 \\
\hline Proroctwa & $\begin{array}{l}\text { Jesteś do niczego. Nikt porządny z ciebie nie } \\
\text { wyrośnie. }\end{array}$ & 98 & 61,25 \\
\hline $\begin{array}{l}\text { Uogólnianie } \\
\text { i generalizo- } \\
\text { wanie }\end{array}$ & $\begin{array}{l}\text { Karol, ty zawsze wszystko psujesz, jeszcze } \\
\text { nigdy nie byłeś porządnie przygotowany, nie } \\
\text { masz żadnych pomystów. Wszyscy nauczy- } \\
\text { ciele mają ciebie dość. }\end{array}$ & 90 & 56,25 \\
\hline $\begin{array}{l}\text { Postawa } \\
\text { męczennika }\end{array}$ & $\begin{array}{l}\text { Jak wy sie zachowujecie? Wykończycie } \\
\text { mnie... Doprowadzicie mnie do grobu... Czy } \\
\text { chcecie, abym dostała przez was zawatu? }\end{array}$ & 87 & 54,37 \\
\hline $\begin{array}{l}\text { Sarkazm, } \\
\text { dowcipko- } \\
\text { wanie }\end{array}$ & $\begin{array}{l}\text { Nie pamiętacie, kiedy Kolumb odkryt Ame- } \\
\text { rykę? To chyba szkoła dla opóźnionych } \\
\text { w rozwoju. Iloraz inteligencji wzrośnie tylko } \\
\text { wtedy, gdy staniecie na krzestach. }\end{array}$ & 78 & 48,75 \\
\hline Groźby & $\begin{array}{l}\text { Jeśli nie zrobisz wszystkich zalegtych prac } \\
\text { domowych do jutra, będziesz powtarzat klasę. }\end{array}$ & 70 & 43,75 \\
\hline Rozkazy & $\begin{array}{l}\text { Jeszcze nie zrobiteś tych zadań. Masz je } \\
\text { natychmiast zrobić!!! }\end{array}$ & 65 & 40,62 \\
\hline Zaprzeczanie & $\begin{array}{l}\text { Nie obchodza mnie twoje emocje. To niemoż- } \\
\text { liwe, żebyś byt zły. Nie ptacz, nie ma powo- } \\
\text { du do płaczu. }\end{array}$ & 60 & 37,50 \\
\hline
\end{tabular}

Źródło: badania własne. 
Jak wynika z analizy tabeli, większość respondentów potrafiła wskazać bariery w komunikacji. Stosunkowo najmniej badanych uznało, że komunikat jest barierą w sytuacji zaprzeczania emocjom i stosowania sarkazmu. Można by przypuszczać, że umiejętność nazywania emocji, a przede wszystkim akceptowania emocji ucznia, nie jest popularna wśród badanych nauczycieli. Być może nie są oni jeszcze gotowi, aby akceptować emocje, które ich zdaniem nie powinny dzieci odczuwać w określonej sytuacji. Osoby, które wskazały, że ten komunikat jest błędem, argumentowały, że nauczycielowi brakuje empatii, że jest niewrażliwy, lekceważy ucznia oraz że nie potrafi nazywać emocji uczniów. Nazewnictwo pochodzące z teorii komunikacji i określające, że tego typu komunikat jako zaprzeczanie emocji pojawiło się tylko trzy razy. Komunikat jako przykład sarkazmu określany był jako brak empatii, krytyka, poniżanie, obrażanie, możliwość obniżenia poczucia wartości u ucznia.

Największe zróżnicowanie wystąpiło przy komunikacie typu ocena ucznia. Aż 110 osób badanych nie zaznaczyło, że może on stanowić barierę w komunikacji. Oznacza to, że nazwanie ucznia leniwym dla tej grupy nauczycieli nie jest niczym złym i można w ten sposób mówić do podopiecznych. Dwadzieścia dwie osoby w objaśnieniu do tego zwrotu napisały, że jest to ocena zbyt rygorystyczna, kilkoro wyraziło zwątpienie, skąd właściwie nauczyciel ma pewność, że uczeń jest leniwy. Można wywnioskować, że sam fakt oceny ucznia nie jest niewłaściwy, ważne tylko, aby ocena była wiarygodna. Inne osoby wskazały, że taka wypowiedź może być demotywująca.

Tego typu wyniki badań skłaniają do refleksji: czy, a jeśli to jak, ocena słowna związana z wydaniem opinii o uczniu, nazwaniem jego cech osobowościowych wpływa na dalsze zachowanie, a nawet rozwój dziecka? Siedemdziesiąt osób wskazało, że komunikat - groźba jest błędem. Jednakże, uzasadnienie takiej decyzji pokazuje, że blokadę nie stanowi samo grożenie, tylko nierealność postawionych wymagań. Duża część nauczycieli pisała bowiem, że uczniowi została postawiona zbyt wysoko poprzeczka, że nauczyciel dał za krótki czas, że należy dać mu dłuższy okres na poprawę. Jeden z nauczycieli tak oto skomentował ten komunikat: Jeśli uczeń nie zrobit czegoś przez cały rok, to i tak nie zrobi.

W przypadku komunikatu - rozkazu sześćdziesiąt pięć osób wskazało, że jest on barierą. Określając, w czym tkwi błąd w tej wypowiedzi, dwudziestu nauczycieli napisało, że jest to ton rozkazujący lub nakazywanie. Pojawiły się także inne wyjaśnienia: postawa dyktatorska jeszcze nigdy nie rozwiązała problemów, nauczyciel nie szuka przyczyn problemu, to samo można powiedzieć delikatniej i przyjemniej, dane polecenie jest niewykonalne.

Wśród barier w komunikacji pomiędzy nauczycielem a uczniem może pojawić się proroctwo. W większości uzasadnień padało stwierdzenie, że jest to zbyt ostra krytyka, całkowita negacja, poniżanie i obrażanie ucznia, 
podcinanie skrzydeł, jak również że taki komunikat może stać się przyczyną uczniowskiej tragedii. Były także wypowiedzi typu: komunikat obniżający u uczniów poczucie wartości siebie oraz że nie wolno w ten sposób osądzać dzieci, że nie powinno się negować uczniów. Przekonywano jednocześnie, że ten komunikat jest właśnie proroctwem, a przecież nikt nie zna przyszłości i nie wiadomo, co może się wydarzyć.

Zaprezentowano także pomysły, co można w zamian: w każdym dziecku należy odkrywać coś dobrego, lepiej koncentrować się na pozytywach, wyrażać się w łagodniejszy sposób. Ktoś napisał konkretne zdanie, które nauczyciel może powiedzieć do ucznia: Postaraj się zmienić swoją postawe, wyjdzie ci to na dobre. Niestety, ta wypowiedź jest też w zasadzie blokadą w komunikacji, gdyż będąc radą, w pewnym sensie zawiera także proroctwo, przewidywanie przyszłości.

Najlepiej zinterpretowano komunikat będący porównywaniem danego ucznia z jego rodzeństwem lub inną osobą. Wszyscy nauczyciele napisali, że jest to niewłaściwy sposób postępowania, bardzo rzadko motywujący ucznia do pracy oraz do zmiany zachowania.

W postawie męczennika nauczyciele wskazywali, że wypowiadający się pedagog zbyt mocno jest skoncentrowany na sobie, pokazuje swoją bezsilność, co nie jest wskazane. Była także mowa o tym, że tego typu wypowiedź może wzbudzać poczucie winy u uczniów.

Stosowanie w wydawaniu opinii o uczniach określeń typu uogólnienia i generalizowanie zostało sklasyfikowane jako błąd, jednak w uzasadnieniu nie zawsze zwracano na to uwagę. Podkreślano nieprawidłową krytykę, która może wpłynąć na obniżenie samooceny dziecka na całkowity spadek jego motywacji do działania.

W ankiecie znajdowało się także pytanie otwarte. Respondenci otrzymali polecenie wpisania tego, co według nich może stanowić barierę pomiędzy nauczycielem a uczniem. Odpowiedzi można podzielić na trzy grupy przyczyn będących po stronie: nauczycieli, uczniów i osób związanych z organizacją pracy w szkole.

Po stronie nauczycieli najczęściej pojawiały się bariery: postawa zamknięta, niesłuchanie uczniów, obrażanie, osądzanie, poniżanie, traktowanie siebie jako kogoś lepszego, porównywanie, szufladkowanie, rutyna, negatywne nastawienie nauczycieli, że uczniowie sobie i tak nie poradzą, brak znajomości sytuacji życiowej dziecka, brak empatii, frustracja nauczycieli, przypadkowość w tym zawodzie, wygłaszanie długich monologów, zbyt żywe emocje nauczyciela, który nie potrafi zostawić swoich problemów za drzwiami, brak ochoty do rozmowy, poczucie wyższości nauczycieli, że jako elita są mądrzejsi od wszystkich, brak zrozumienia ucznia, brak umiejętności postawienia się w jego sytuacji, brak autorytetu, złe doświadczenia w poprzedniej szkole. Po 
stronie uczniów była to: wrogość do przedmiotu, brak ochoty do rozmowy, brak umiejętności rozmowy ze względu na to, że się z dziećmi nie rozmawia w domu. Trzecią grupę stanowiły wypowiedzi typu: brak czasu na indywidualne rozmowy, zbyt liczne klasy, zbyt dużo zadań biurokratycznych.

\section{Uwagi i wnioski końcowe}

$\mathrm{W}$ artykule podjęto problem kompetencji komunikacyjnych nauczycieli jako szczególnie ważny dla efektywności pracy dydaktyczno-wychowawczej szkoły współczesnej. W części teoretycznej zdefiniowano więc proces komunikowania się, omówiono style komunikowania się nauczycieli z uczniami oraz scharakteryzowano podstawowe bariery komunikacji wychowawczej.

W części empirycznej przedstawiono wyniki badań diagnostycznych, przeprowadzonych techniką ankiety wśród czynnych nauczycieli.

Zasadnicza część badanej grupy nauczycieli docenia wagę komunikacji pomiędzy różnymi grupami społecznymi zaangażowanymi w pracę szkoły, czyli nauczycielami, uczniami i rodzicami. Do najważniejszych spraw zaliczają oni dialog pomiędzy nauczycielem a uczniem. Uważają, że należy dbać, aby komunikacja odbywała się w odpowiednim otoczeniu, czasie i miejscu. Traktują ją jako sposób poznania ucznia i zrozumienia jego zainteresowań, potrzeb oraz całej osobowości.

Spory zespół pedagogów (42,5\%) komunikację traktuje głównie jako transmisję wiedzy i przepływ informacji. Była też grupa nauczycieli, którzy zwrócili uwagę na odpowiedni dobór słów, na ich piękno i adekwatność względem sytuacji komunikowania się.

Prawie połowa badanych nauczycieli oceniła, że ich umiejętności komunikacyjne osiągnęły poziom średni. Respondenci uważali, że głównym źródłem rozwoju kompetencji komunikacyjnych są doświadczenia w realnych relacjach z uczniami i sytuacjach szkolnych. Stosunkowo mało, bo tylko 7,5\% wskazało na kursy i szkolenia z zakresu komunikacji jako miejsce doskonalenia tych umiejętności.

Drugi problem ogólny naszych badań dotyczył stylów komunikowania się. Styl komunikowania wśród nauczycieli można w 47,5\% zaliczyć do stylu współpracującego, w 43,1\% - do stylu mieszanego i w 9,4\% - do stylu autorytarnego. Ważne jest, że 46,9\% nauczycieli używa pytań otwartych, a raczej stroni od zamkniętych. Cieszy zapewne fakt, że wszyscy nauczyciele deklarują potrzebę bycia empatycznym $\mathrm{w}$ relacji z uczniami.

Jednocześnie, niestety, 75\% nauczycieli nie wskazało, że konkretny komunikat, będący zaprzeczeniem emocji, stanowi barierę $\mathrm{w}$ komunikacji. W większości nauczyciele potrafią ogólnie wskazać bariery w komunikacji, 
mają świadomość, że mogą one występować zarówno po stronie ucznia, jak i nauczyciela.

Zasadniczym zadaniem dla osób pracujących wśród nauczycieli powinno być przekonanie ich, że podczas warsztatów i kursów z zakresu komunikacji mogą doskonalić swoje umiejętności komunikacyjne, jednak pod warunkiem, że będą dobrze zmotywowani, a nawet zdeterminowani, żeby uważać, co się mówi i jak się słucha.

\section{BIBLIOGRAFIA}

Bocheńska-Włostowska K., Akademia umiejętności interpersonalnych. 20 spotkań z komunikacją, Oficyna Wydawnicza Impuls, Kraków 2009.

Czerepaniak-Walczak M., Aspekty i źródła profesjonalnej refleksji nauczycieli, Wydawnictwo Edytor, Torun 1997.

Czerepaniak-Walczak M., Kompetencja: stowo kluczowe czy "wytrych" w edukacji, Neodidagmata, XXIV, Poznań 1999.

Davis M.H., Empatia. O umiejętności wspótodczuwania, Gdańskie Wydawnictwo Psychologiczne, Gdańsk, 1999.

Dawid J.W., O duszy nauczycielstwa, Wydawnictwo KUL, Lublin 2002.

Dylak S., Zawodowe kompetencje nauczyciela, [w:] Edukacja. Technologia kształcenia. Media, red. K. Denek, F. Januszkiewicz, W. Strykowski, Polski Dom Wydawniczy Ławica, Poznań 1993.

Dziewiecki M., Komunikacja wychowawcza, Wydawnictwo Salwator, Kraków 2004.

Gołębniak B., Nauczanie i uczenie się w klasie, [w:] Pedagogika. Podręcznik akademicki, t. 2, red. Z. Kwieciński, B. Śliwerski, Wydawnictwo Naukowe PWN, Warszawa 2003.

Gordon T., Wychowanie bez porażek w szkole, Instytut Wydawniczy PAX, Warszawa 2007.

Grzesiuk L., Style komunikacji interpersonalnej, Wydawnictwo Uniwersytetu Warszawskiego, Warszawa 1979.

Grzesiuk L., Trzebińska E., Jak ludzie porozumiewają się, Wydawnictwo Nasza Księgarnia, Warszawa 1978.

Kozyra B., Komunikacja bez barier, Wydawnictwo MT Biznes, Warszawa 2008.

Król-Fijewska M., Stanowczo, tagodnie, bez lęku, Wydawnictwo W.A.B., Warszawa 2012.

Kwaśnica R., Wprowadzenie do myślenia o nauczycielu, [w:] Pedagogika. Podręcznik akademicki, t. 2. red. Z. Kwieciński, B. Śliwerski, Wydawnictwo Naukowe PWN, Warszawa 2003.

MacKenzie R.J., Kiedy pozwolić, kiedy zabronić w klasie, Gdańskie Wydawnictwo Psychologiczne, Gdańsk 2008.

Mrozowski M., Media masowe. Wtadza, rozrywka i biznes, Oficyna Wydawnicza ASPRA-JR, Warszawa 2001.

Nęcki Z., Komunikacja międzyludzka, Wydawnictwo Profesjonalnej Szkoły Biznesu, Kraków 1996. 